\title{
STUDI DESKRIPTIF INTERAKSI SOSIAL MAHASISWA S1 JURUSAN ILMU PENDIDIKAN BERDASARKAN KETERLIBATAN ORGANISASI KEMAHASISWAAN DI FAKULTAS KEGURUAN DAN ILMU PENDIDIKAN UNIVERSITAS BENGKULU
}

\author{
Prita Dwi Astuti, Hadiwinarto, Afifatus Sholihah \\ Prodi Bimbingan dan Konseling Fakultas Keguruan dan Ilmu Pendidikan \\ Universitas Bengkulu \\ prita22dwi@gmail.com, hadiwin@unib.ac.id, afifatus@unib.ac.id
}

\begin{abstract}
ABSTRAK
Penelitian ini bertujuan untuk mendeskripsikan interaksi sosial mahasiswa S1 Jurusan Ilmu Pendidikan berdasarkan keterlibatan dalam kegiatan organisasi kemahasiswaan di Fakultas Keguruan dan Ilmu Pendidikan Universitas Bengkulu”. Metode penelitian yang digunakan adalah metode deskriptif. Pengambilan subjek penelitian menggunakan teknik simple random sampling sehingga didapat sampel sebanyak 158 mahasiswa. Data diperoleh melalui pemberian angket. Teknik analisis data yang digunakan yaitu analisis deskriptif dengan perhitungan persentase. Berdasarkan hasil penelitian diperoleh bahwa interaksi sosial mahasiswa S1 Jurusan Ilmu Pendidikan berdasarkan keterlibatan dalam kegiatan organisasi kemahasiswaan di FKIP Universitas Bengkulu, menunjukan bahwa 2\% mahasiswa memiliki tingkat keterlibatan organisasi yang sangat tinggi, tingkat keterlibatan organisasi tinggi mayoritas memiliki tingkat interaksi sosial yang tinggi pula dengan persentase $56 \%$ sedangkan tingkat keterlibatan organisasi rendah mayoritas memiliki tingkat interaksi sosial yang rendah pula dengan persentase $44 \%$, selain itu terdapat $1 \%$ mahasiswa dengan tingkat keterlibatan organisasi sangat rendah.
\end{abstract}

Kata kunci: interaksi sosial, keterlibatan organisasi kemahasiswaan

\section{DESCRIPTIVE STUDY OF SOCIAL INTERACTION OF UNDERGRADUATE STUDENTS OF DEPARTMENT OF EDUCATIONAL SCIENCES BASED ON STUDENT ORGANIZATION INVOLVEMENT AT THE FACULTY OF TEACHER TRAINING AND EDUCATION UNIVERSITY OF BENGKULU}

\begin{abstract}
The purpose of this study is to describe social interactions of undergraduate students of Education Departement based on their involvement in student organization at the faculty of teacher training and education university of Bengkulu". The research method used in this study was descriptive method. This study used simple random sampling technique to obtain 158 students as the sample. The data were obtained throught questionnaire. Technique of analysis data in this study was descriptive analysis with percentage calculation. Based on the result of this study, it is found that student sosial interaction of S1 departement of education based on involvement in student organization involvement at FKIP University Of Bengkulu showed that $2 \%$ of student have a very high level of organization involvement, high level of high organization involvement level have a high degree of social interaction with percentages $56 \%$, while the low level of involvement of the majority organization has a low level of social interaction with percentages of $44 \%$, and there $1 \%$ of students with very low organization involvement level.
\end{abstract}

Keywords: social interaction, student organization involvement

Jurnal Ilmiah Bimbingan dan Konseling, Volume 1 Nomor 22018 FKIP Universitas Bengkulu 


\section{Pendahuluan}

Pendidikan sebagai upaya peningkatan pembinaan dan pengembangan sumber daya manusia diharapkan mampu melahirkan manusia Indonesia yang bermutu dan memiliki kepribadian maju dan mandiri agar mampu menghadapi tantangan era globalisasi dan informasi.

Universitas merupakan lembaga pendidikan dan juga tempat studi berbagai kegiatan ilmu yang di dalamnya juga memiliki kegiatan organisasi yaitu organisasi kemahasiswaan (Sartika dkk, 2016: 4). Keputusan Menteri Pendidikan dan Kebudayaan Nomor 155/U/1998 tentang Pedoman Umum Organisasi Kemahasiswaan dijelaskan bahwa organisasi kemahasiswaan adalah wahana dan sarana pengembangan diri mahasiswa kearah perluasan wawasan dan peningkatan kecendikiawanan serta integritas kepribadian untuk mencapai tujuan pendidikan tinggi (Caesari dkk, 2013: 165).

Organisasi kemahasiswaan dapat dijadikan tempat untuk menggali bakat dan minat yang dimiliki oleh mahasiswa dan dapat dijadikan tempat untuk berinteraksi dan mencari teman sebanyak-banyaknya. Dalam organisasi, individu sebagai anggota mempunyai hubungan yang mendalam dengan anggota lainnya. Hubungan tersebut dapat berupa hubungan interaksi sosial antar anggota dan pimpinan organisasi atau anggota atau pimpinan organisasi lain.

Interaksi sosial menurut Walgito (2008: 57) adalah hubungan antara individu satu dengan individu yang lain, individu satu dapat mempengaruhi individu lain atau sebaliknya, jadi terdapat adanya hubungan saling timbal balik. Senada dengan pendapat diatas, Widayanti (2005: 28) menjelaskan bahwa interaksi sosial merupakan suatu hubungan yang dilakukan antara individu atau antara manusia yang satu dengan manusia atau individu yang lain, dalam interaksi itu terjadi suatu hubungan timbal balik antara kedua belah pihak.

Mahasiswa dapat memanfaatkan berbagai bentuk kegiatan organisasi kemahasiswaan yang tersedia di kampus untuk membiasakan dirinya hidup bersama dan mengembangkan pergaulan yang akrab dengan orang lain (Nashori dalam Akhir, 2014: 26). Kesempatan untuk mengembangkan pergaulan yang akrab dengan orang lain antara lain dapat diperoleh dengan cara terlibat dalam kegiatan kemahasiswaan.

Berdasarkan hasil observasi dilapangan selama mengikuti perkuliahan di Universitas Bengkulu menunjukan 
bahwa mahasiswa yang terlibat dalam kegiatan organisasi mempunyai kemampuan yang baik dalam berinteraksi sosial. Hal tersebut sejalan dengan pernyataan yang dikemukakan Akhir (2014: 29) dimana mahasiswa yang terlibat dalam berbagai kegiatan di kampus umumnya akan memiliki interaksi sosial yang lebih baik dibandingkan dengan mahasiswa yang tidak terlibat dalam kegiatan-kegiatan dikampus.

Penelitian ini secara umum bertujuan untuk mendeskripsikan interaksi sosial mahasiswa S1 Jurusan Ilmu Pendidikan berdasarkan keterlibatan dalam kegiatan organisasi kemahasiswaan di Fakultas Keguruan dan Ilmu Pendidikan Universitas BengkuluAdapun tujuan penelitian secara khusus meliputi mendeskripsikan hubungan sosial, kerjasama, komunikasi, asimilasi, dan penyesuaian diri mahasiswa S1 Jurusan Ilmu Pendidikan berdasarkan keterlibatan dalam kegiatan organisasi kemahasiswaan di Fakultas Keguruan dan Ilmu Pendidikan Universitas Bengkulu.

\section{Metode Penelitian}

Penelitian ini merupakan penelitian deskriptifJenis penelitian deskriptif yang digunakan dalam penelitian ini adalah penelitian survei. Menurut Fraenkel dan dan Wallen (dalam Zuriah, 2009:47) penelitian survei merupakan penelitian yang mengumpulkan informasi dari suatu sampel dengan menanyakan melalui angket atau interview agar nantinya menggambarkan sebagai aspek dari populasi.

Subjek Penelitian ini adalah mahasiswa $\mathrm{S} 1$ jurusan ilmu pendidikan fakultas keguruan dan ilmu pendidikan universitas Bengkulu yang terlibat dalam kegiatan organisasi yang berjumlah 260 orang. Namun yang akan dijadikan sampel penelitian berjumlah 158 mahasiswa. Teknik pengambilan sampel pada penelitian menggunakan SimpleRandom Sampling atau subyek penelitianberpeluang yang samauntuk menjadi sampel atau untuk mewakili populasi.

\section{Hasil dan Pembahasan}

Uji validitas diberikan terhadap 30 responden. Hasil uji validitas angket interaksi sosial diperoleh hasil bahwa angket interaksi sosial yang diberikan kepada 30 responden yang terdiri dari 45 butir pernyataan interaksi sosial, diperoleh 11 butir angket yang dinyatakan gugur dan 33 butir angket yang dinyatakan valid. Sedangkan hasil uji validitas angket keterlibatan organisasi diperoleh hasil bahwa angket keterlibatan organisasi yang diberikan kepada 30 responden yang terdiri dari 15 butir pernyataan keterlibatan 
organisasi, diperoleh 4 butir angket yang dinyatakan gugur dan 11 butir angket yang dinyatakan valid.

Sedangkan berdasarkan hasil analisis uji reabilitas menunjukkan bahwa nilai Cronbach's Alpha sebesar 0,955 sehingga dapat dinyatakan instrument tersebut memiliki realibitas baik. Untuk hasil analisis uji reliabilitas keterlibatan organisasi menunjukkan bahwa nilai Cronbach's Alpha sebesar 0,919 sehingga dapat disimpulkan bahwa instrument tersebut memiliki realibitas baik.

Hasil data yang diperoleh dipersentasikan berdasarkan bentuk dan komponen interaksi sosial yang terdiri dari hubungan sosial, kerja sama, komunikasi, asimilasi, penyesuaian diri dan keterlibatan organisasi. Skala interaksi sosial yang digunakan pada penelitian ini menggunakan rentang skor dari 1-4, adapun kategorinya adalah; 1) Sangat rendah 2) Rendah 3) Tinggi, dan 4) Sangat tinggi. Kategori nilai akhir interaksi sosial diambil dari skor angket interaksi sosial berdasarkan skor ideal.

Adapun distribusi dan kategori hasil interaksi sosial adalah sebagai berikut:

Tabel 1.

Distribusi dan Kategori Interaksi Sosial

\begin{tabular}{cccc}
\hline Skor & Kategori & Frekuensi & Persentase \\
\hline $108-132$ & Sangat & 0 & $0 \%$
\end{tabular}

\begin{tabular}{cccc}
\hline \multicolumn{5}{c}{ tinggi } & & \\
\hline $83-107$ & Tinggi & 88 & $56 \%$ \\
\hline $58-82$ & Rendah & 70 & $44 \%$ \\
\hline $33-57$ & $\begin{array}{l}\text { Sangat } \\
\text { rendah }\end{array}$ & 0 & $0 \%$ \\
\hline
\end{tabular}

Berdasarkan tabel di atas menunjukkan bahwa mahasiswa jurusan ilmu pendidikan yang terlibat dalam organisasi kemahasiswaan memiliki interaksi sosial yang tinggi dengan jumlah 88 mahasiswa atau sebanyak $56 \%$ sedangkan yang rendah dengan jumlah 70 mahasiswa atau sebanyak $44 \%$.

Untuk distribusi dan kategori hasil hubungan sosial meliputi sebagai berikut:

Tabel 2.

Distribusi dan Kategori Hubungan Sosial

\begin{tabular}{cccc}
\hline Skor & Kategori & Frekuensi & Persentase \\
\hline $26-32$ & $\begin{array}{c}\text { Sangat } \\
\text { tinggi }\end{array}$ & 0 & $0 \%$ \\
\hline $20-25$ & Tinggi & 83 & $53 \%$ \\
\hline $14-19$ & Rendah & 70 & $44 \%$ \\
\hline $8-13$ & $\begin{array}{l}\text { Sangat } \\
\text { rendah }\end{array}$ & 5 & $3 \%$ \\
\hline
\end{tabular}

Berdasarkan tabel di atas menunjukkan bahwa hubungan sosial yang dimiliki oleh 158 mahasiswa yang menjadi sampel memiliki skor dengan kategori tinggi sebanyak 83 mahasiswa dengan persentase 53\%, 70 mahasiswa dalam kategori rendah dengan persentase $44 \%$ dan 5 mahasiswa dalam kategori sangat rendah dengan persentase 3\%. Untuk distribusi dan 
kategori hasil kerjasama meliputi sebagai berikut:

Tabel 3.

Distribusi dan Kategori Kerjasama

\begin{tabular}{cccc}
\hline Skor & Kategori & Frekuensi & Persentase \\
\hline $13-16$ & $\begin{array}{c}\text { Sangat } \\
\text { tinggi }\end{array}$ & 8 & $5 \%$ \\
\hline $10-12$ & Tinggi & 80 & $51 \%$ \\
\hline $7-9$ & Rendah & 65 & $41 \%$ \\
\hline $4-6$ & $\begin{array}{l}\text { Sangat } \\
\text { rendah }\end{array}$ & 5 & $3 \%$ \\
\hline
\end{tabular}

Berdasarkan tabel di atas menunjukkan bahwa kerjasama yang dimiliki oleh 158 mahasiswa yang menjadi sampel memiliki skor dengan kategori sangat tinggi sebanyak 8 mahasiswa dengan persentase 5\%, tinggi sebanyak 80 mahasiswa dengan persentase $51 \%, 65$ mahasiswa dalam kategori rendah dengan persentase $41 \%$ dan 5 mahasiswa dalam kategori sangat rendah dengan persentase 3\%. Untuk distribusi dan kategori hasil komunikasi meliputi sebagai berikut:

Tabel 4.

Distribusi dan Kategori Komunikasi

\begin{tabular}{cccc}
\hline Skor & Kategori & Frekuensi & Persentase \\
\hline $34-42$ & Sangat tinggi & 4 & $3 \%$ \\
\hline $25-33$ & Tinggi & 80 & $51 \%$ \\
\hline $18-24$ & Rendah & 74 & $46 \%$ \\
\hline $10-17$ & $\begin{array}{l}\text { Sangat } \\
\text { rendah }\end{array}$ & 0 & $0 \%$ \\
\hline
\end{tabular}

Berdasarkan tabel di atas menunjukkan bahwa komunikasi yang dimiliki oleh 158 mahasiswa yang menjadi sampel memiliki skor dengan kategori tinggi sebanyak 80 mahasiswa dengan persentase $51 \%, 74$ mahasiswa dalam kategori rendah dengan persentase $46 \%$ dan 4 mahasiswa dalam kategori sangat rendah dengan persentase 3\%. Untuk distribusi dan kategori hasil asimilasi meliputi sebagai berikut:

Tabel 5.

Distribusi dan Kategori Asimilasi

\begin{tabular}{cccc}
\hline Skor & Kategori & Frekuensi & Persentase \\
\hline $26-32$ & $\begin{array}{c}\text { Sangat } \\
\text { tinggi }\end{array}$ & 3 & $2 \%$ \\
\hline $20-25$ & Tinggi & 84 & $44 \%$ \\
\hline $14-19$ & Rendah & 69 & $53 \%$ \\
\hline $8-13$ & $\begin{array}{l}\text { Sangat } \\
\text { rendah }\end{array}$ & 2 & $1 \%$ \\
\hline
\end{tabular}

Berdasarkan tabel di atas menunjukkan bahwa asimilasi yang dimiliki oleh 158 mahasiswa yang menjadi sampel memiliki skor dengan kategori sangat tinggi sebanyak 3 mahasiswa dengan persentase $2 \%$, tinggi sebanyak 84 mahasiswa dengan persentase 53\%, 69 mahasiswa dalam kategori rendah dengan persentase $44 \%$ dan 2 mahasiswa dalam kategori sangat rendah dengan persentase $1 \%$.

Untukdistribusi dan kategori hasil penyesuaian diri meliputi sebagai berikut: 
Tabel 6.

Distribusi dan KategoriPenyesuaian Diri

\begin{tabular}{cccc}
\hline Skor & Kategori & Frekuensi & Persentase \\
\hline $10=12$ & $\begin{array}{c}\text { Sangat } \\
\text { tinggi }\end{array}$ & 15 & $10 \%$ \\
\hline $7-10$ & Tinggi & 97 & $61 \%$ \\
\hline $4-6$ & Rendah & 45 & $28 \%$ \\
\hline $0-3$ & $\begin{array}{c}\text { Sangat } \\
\text { rendah }\end{array}$ & 1 & $1 \%$ \\
\hline
\end{tabular}

Berdasarkan tabel di atas menunjukkan bahwa penyesuaian diri yang dimiliki oleh 158 mahasiswa yang menjadi sampel memiliki skor dengan kategori sangat tinggi sebanyak 15 mahasiswa dengan persentase $10 \%$, tinggi sebanyak 97 mahasiswa dengan persentase $61 \%, 45$ mahasiswa dalam kategori rendah dengan persentase $28 \%$ dan 1 mahasiswa dalam kategori sangat rendah dengan persentase $1 \%$.

Berdasarkan sampel penelitian yang berjumlah 158 mahasiswa menunjukan tabulasi hasil analisis data bahwa mayoritas mahasiswa yang terlibat dalam kegiatan organisasi memiliki tingkat interaksi sosial yang lebih tinggi. Hal ini dikarenakan dalam suatu keterlibatan organisasi, mahasiswa dapat belajar banyak hal dan akan memperoleh banyak pengalaman serta dapat berinterasi dengan banyak mahasiswa lainnya. Hal ini sejalan dengan yang dikemukakan oleh Widayanti (2005: 41) yang mengatakan bahwa mahasiswa yang mengikuti organisasi dan aktif dalam kegiatan akan mendapatkan pengalaman dan terbiasa melakukan hubungan dengan orang lain, sehingga mereka mempunyai kemampuan lebih baik dalam menjalin hubungan timbal balik dengan orang lain.

Sedangkan mahasiswa yang memiliki tingkat interaksi sosial yang rendah memiliki beberapa faktor salah satunya yaitu sikap selalu berkelompok, yang artinya mahasiswa lebih suka membuat kelompok-kelompok kecil berdasarkan kesamaan-kesamaan yang dimiliki dan kurang membuka diri untuk bergaul dengan orang dari luar kelompoknya. hal itu sesuai dengan pendapat Indrawijaya (2002: 98) yaitu kelompok informal berkembang atas dasar perasaan saling tertarik, karena kebutuhan akan tukar menukar informasi, untuk saling melengkapi ataupun karena kesamaan sikap.

Dilihat dari perhitungan pada tiap subvariabel menunjukkan bahwa hasil sangat bervariasi. Dalam hal hubungan sosial, mayoritas mahasiswa memiliki tingkat hubungan sosial yang tinggi. Setiap individu memiliki hubungan sosial yang berbeda-beda. Hubungan sosial dapat juga terjalin diluar suatu organisasi, misalnya pada lingkungan sosial. Namun dalam suatu 
organisasi lebih mudah untuk meningkatkan hubungan sosialnya dikarenakan adanya keinginan untuk memiliki rasa persahabatan dan kekeluargaan dengan anggota suatu organisasi yang diikuti. Hal ini sesuai dengan pendapat Indrawijaya (2002: 89) yang mengatakan bahwa manusia dalam setiap organisasi selain bekerja untuk mencapai tujuan organisasi juga berusaha untuk memenuhi kebutuhan sosial mereka seperti rasa persahabatan, rasa kekeluargaan, dan rasa sesama. Sehingga hubungan sosial yang dimiliki mahasiswa akan lebih baik dan berkualitas.

Berdasarkan pada submasalah kerjasama, mayoritas memiliki tingkat kerjasama yang tinggi hal ini dikarenakan dalam kegiatan organisasi, kerjasama sesama anggota sangat diperlukan karena pada dasarnya individu tidak dapat melakukan semuanya sendiri. Kegiatan organisasi juga dapat meningkatkan tingkat kerjasama mahasiswa karena dalam kegiatan organisasi akan sangat sering melakukan kegiatan kerjasama baik untuk sesama anggota maupun antar organisasi lainnya. Hal ini senada dalam penelitian Widyaningsih (2010: 62) yang menyatakan bahwa kerjasama tampak pada saat menjalankan program yang telah dirangcang sebelumnya.

Berdasarkan pada submasalah komunikasi, mayoritas mahasiswa memiliki tingkat komunikasi yang tinggi. Hal itu dikarenakan komunikasi merupakan salah satu cara individu untuk berinteraksi sosial. Terlebih dalam suatu kegiatan organisasi diperlukan kemampuan komunikasi yang cukup baik. Hal itu sejalan dengan yang dikemukakan oleh Indrawijaya (2002:104) yang mengatakan bahwa Komunikasi antar perorangan merupakan salah satu aspek penting dalam mempelajari perilaku dalam kelompok atau organisasi.

Berdasarkan pada submasalah asimilasi, mayoritas memilii tingkat asimilasi yang tinggi. Asimilasi atau peleburan kebudayaan sangat banyak dapat ditemui didunia perkuliahan karena banyak mahasiswa yang berasal dari luar daerah yang berbeda-beda. Untuk itu penerimaan dan rasa toleransi sangat diperlukan dalam menjalin pertemanan. Terlebih dalam mengikuti kegiatan organisasi, pasti memiliki anggota dari berbagai daerah, suku dan agama. Hal ini sesuai dengan pendapat Festinger dalam Indrawijaya (2002: 93) yang mengemukakan bahwa orang yang memasuki suatu kelompok pada hakikatnya mempunyai dorongan untuk 
mengadakan evaluasi terhadap dirinya, dengan memasuki kelompok atau organisasi seseorang akan tahu pendapat orang lain mengenai dirinya, termasuk tentang apa yang baik, yang boleh, dan yang tidak boleh dikerjakan.

Berdasarkan pada submasalah penyesuaian diri, mayoritas mahasiswa memiliki tingkat penyesuaian diri yang tinggI. Penyesuaian diri sangat penting untuk dapat melakukan interaksi sosial, baik penyesuaian diri dengan lingkungan sekitar maupun dengan orang lain disekitar. Terlebih dalam keterlibatan organisasi, individu perlu memiliki penyesuaian diri yang baik agar mampu bersosialisasi dengan anggota kelompok yang lainnya agar dapat menambah pengalaman mahasiswa dalam berinteraksi. Hal ini sejalan dengan yang dikemukakan oleh Indrawijaya (2002: 37) yaitu kepribadian seseorang dipengaruhi oleh pengalamannya termasuk interaksinya dengan lingkungan, karena interaksi dengan lingkungan merupakan suatu bagian penting dari proses belajar.

Perbedaan hasil subvariabel disebabkan adanya beberapa faktor yang mempengaruhi perilaku interaksi sosial seseorang. Tidak semua mahasiswa yang terlibat dalam suatu organisasi kemahasiswaan memiliki tingkat interaksi sosial serta subvariabel interaksi sosial yang tinggi, mereka yang terlibat dalam suatu organisasi juga dapat memiliki tingkat interaksi sosial yang rendah. Hal ini sejalan dengan yang dikemukakan oleh Herbert Blumer (dalam Soekanto, 2002: 62) yaitu proses interaksi sosial adalah pada saat manusia bertindak terhadap sesuatu atas dasar makna yang dimiliki sesuatu tersebut bagi manusia. Kemudian makna yang dimiliki sesuatu itu berasal dari interaksi sosial antara seseorang dengan sesamanya.

Peningkatan interaksi sosial tidak hanya dapat dilakukan dalam kelompok organisasi terlebih organisasi kemahasiswaan yang ada di FKIP Universitas Bengkulu, namun juga dapat ditingkatkan melalui kelompok lingkungan sosial. Hal ini sesuai dengan pendapat Widayanti (2005: 77) yang mengatakan bahwa kualitas interaksi sosial seseorang sangat dipengaruhi oleh kondisi lingkungan sosial di mana mereka berada. Semakin berkualitas kelompok sosial yang membentuk pola tingkah laku individu, maha akan semakin berkualitas pula interaksinya pada lingkungan sosial di mana mereka berada.

Pada dasarnya kegiatan perkuliahan mahasiswa tidak hanya memperhatikan 
kegiatan akademik saja. Namun juga keikutsertaan pada organisasi juga memiliki manfaat dan peran bagi mahasiswa, untuk itu keduanya sangat penting bagi mahasiswa. Membagi waktu untuk menjalankan keduanya sangat diperlukan, jangan sampai terlalu fokus untuk salah satunya saja. Hal ini senada dengan pendapat Huang dan Chang (2004: 391) yang menjelaskan bahwa mahasiswa yang aktif dalam kegiatan akademik dan kokurikuler memiliki manfaat dalam penguatan kemampuan berfikir, kemampuan komunikasi,kemampu an interpersonal dan kepercayaan diri.

Penelitian ini akan lebih baik jika sampel penelitian mencakup lebih banyak populasi tidak hanya jurusan ilmu pendidikan, selain itu variabel penelitian juga mencakup lebih banyak aspek tidak hanya aspek positif, namun juga aspek negatif meliputi pertentangan, perselisihan dan persaingan.

\section{Kesimpulan}

Berdasarkan hasil penelitian dapat disimpulkan bahwa, mayoritas mahasiswa yang terlibat dalam kegiatan organisasi kemahasiswaan memiliki tingkat interaksi sosial tergolong tinggi yaitu 56\% mahasiswa, $44 \%$ mahasiswa memiliki tingkat interaksi sosial yang rendah. Adapun secara khusus mayoritas mahasiswa yang terlibat dalam kegiatan organisasi kemahasiswaan memiliki tingkat hubungan sosial, kerjasama, komunikasi, asimilasi dan penyesuaian diri yang tinggi.

\section{Daftar Pustaka}

Akhir, Galang Ilham. (2014). Hubungan Lingkungan Sosial dan Keaktifan Kegiatan di Kampus dengan Kompetensi Sosial Mahasiswa Jurusan Pendidikan Bahasa Prancis Fakultas Bahasa dan Seni Universitas Negeri Yogjakarta. Skripsi. Yogjakarta: Universitas Negeri Yogjakarta

Anonim. (2009). Peraturan Rektor Universitas Bengkulu tentang Aturan Dasar Keluarga Besar Mahasiswa Universitas Bengkulu. Bengkulu

Caesari dkk (2013). "Kuliah Vs Organisasi Studi kasus mengenai strategi belajar pada mahasiswa yang aktif dalam organisasi mahasiswa pecinta alam Universitas Diponegoro. Jurnal Psikologi UNDIP, XII (2), 164-175

Huang, Y. dan Chang, S. (2004). Academic and Cocurricular Involvement: Their Relasionship and Best Combinations for Student Growth. Jurnal Of College Student Development, 45 (4), 391-406

Indrawijaya, Adam I. (2002). Perilaku Organisasi. Bandung: Sinar Baru Algensindo

Sartika dkk. (2016). Interaksi Sosial Kepengurusan Organisasi Himpunan Mahasiswa Sosiologi (HIMSOS) Periode 
Fakultas Ilmu Sosial dan Ilmu Politik (FISIP). Skripsi. Tanjung Pinang: Universitas Maritim Raja Ali Haji

Soekanto, Soerjono. (2002). Sosiologi Suatu Pengantar. Jakarta: Raja Grafindo Persada

Syarbaini, Syahrial dan Rusdiyanta. (2003). Dasar-dasar Sosiologi. Yogjakarta: Graha Ilmu

Tohirin. (2014). Bimbingan dan Konseling di Sekolah dan Madrasah (Berbasis Integrasi. Jakarta: Rajawali Pers

Walgito, Bimo. (2008). Psikologi Sosial (Suatu Pengantar). Yogyakarta: Andi Offset

Widayanti, Anik. (2005). Perbedaan Interaksi Sosial antara Mahasiswa S1 Yang Mengikuti dan Tidak Mengikuti Organisasi Kemahasiswaan di Fakultas Ilmu Pendidikan Universitas Negeri Semarang Tahun Akademik 2004-2005. Skripsi. Semarang: Universitas Negeri Semarang

Yusuf, Syamsu dan A. Juntika. (2005). Landasan Bimbingan \&Konseling. Bandung: Remaja Rosdakarya

Zuriah, Nurul. (2009). Metodologi Penelitian Sosial dan Pendidikan Teori- Aplikasi. Jakarta: PT Bumi Aksara 